\title{
Further Studies on a Hybrid Cell-Surface Antigen Associated with Human Chromosome 11 Using a Monoclonal Antibody
}

\author{
Carol Jones, ${ }^{1,2}$ Kathryn A. Kimmel, ${ }^{5}$ Thomas E. Carey, ${ }^{4,5}$ York E. Miller, ${ }^{1,3}$ \\ David W. Lehman,' and Douglas MacKenzie ${ }^{1}$ \\ Eleanor Roosevelt Institute for Cancer Research, Inc., ${ }^{1}$ Department of Biochemistry, \\ Biophysics and Genetics, ${ }^{2}$ and Department of Medicine, ${ }^{3}$ University of Colorado Health \\ Sciences Center, Denver, Colorado 80262; and The Cancer Research Laboratory in the \\ Department of Otorhinolaryngology, ${ }^{4}$ and Department of Microbiology and Immunology. \\ University of Michigan, Ann Arbor, Michigan 48109
}

Received 25 January 1983

\begin{abstract}
A monoclonal antibody has been obtained that recognizes an antigen encoded by human chromosome 11. We present evidence that this monoclonal antibody recognizes the same or a similar antigenic activity as that previously called $a_{1}$. Genetic information necessary for $a_{1}$ expression and recognition by the monoclonal antibody both map to 11 p13 $\rightarrow 11$ pter. Mutants that have lost $a_{1}$ are no longer recognized by the monoclonal antibody. The macroglycolipid fraction of human erythrocyte membranes which contains the $a_{1}$ antigenic activity is able to convert antigen-negative Chinese hamster ovary cells into cells which are killed by the monoclonal antibody plus complement.
\end{abstract}

\section{INTRODUCTION}

Previous work from this and other laboratories has identified several different human cell-surface antigens coded for by human chromosome 11 using human-rodent somatic cell hybrids (1-7). These antigens have been identified utilizing species-specific antisera. The ability to prepare monoclonal antibodies to these antigens makes more precise analysis possible.

In this paper, we describe an IgM monoclonal antibody that recognizes an antigen coded for by chromosome 11 . This antigen maps on $11 \mathrm{p} 13 \rightarrow$ 11 pter and, using mutant and glycolipid conversion analyses, we show that this monoclonal recognizes the antigen activity we previously designated $a_{1}$ (also referred to as SA11-1 and $\mathrm{S} 1$ ). 


\section{MATERIALS AND METHODS}

Cell Lines and Cell Culture. The following cell lines were used: CHO$\mathrm{K} 1$, a Chinese hamster ovary cell line; $\mathbf{J} 1$, a human-Chinese hamster ovary hybrid which contains human chromosome 11 as its only human chromosome $(8) ; \mathrm{J} 1-7,11,23,35(9,10)$, subclones of $\mathrm{J} 1$; a panel of independently isolated human-Chinese hamster hybrids containing different combinations of human chromosomes; and HeLa and a variant $\mathrm{HeLa}$ line. These cells were cultivated in F12FC5 (11).

For hybridoma production the human cell lines UM-SCC-1, a squamous cell carcinoma line established at the University of Michigan (12), SKMEL-28, a malignant melanoma line (13), WI-38, a normal human fibroblast line, and SK-OV-3, an ovarian adenocarcinoma line, were used. SK-MEL-28, WI-38, and SK-OV-3 were all obtained from the tumor cell bank at the Sloan-Kettering Institute. Human cell lines were maintained in Eagle's minimum essential media (MEM) supplemented with $2 \mathrm{mM}$ glutamine, $1 \%$ nonessential amino acids, $100 \mathrm{IU} / \mathrm{ml}$ penicillin, $100 \mu \mathrm{g} / \mathrm{ml}$ streptomycin, and $15 \%$ fetal bovine serum. NS-1 mouse myeloma cells (14) were obtained from B. Grossman and were cultured in RPMI 1640 medium.

Hybridoma Isolation and Monoclonal Antibody Production. BALB/c mice were immunized intraperitoneally with 30 million viable cells of the human squamous cell carcinoma line UM-SCC-1. At 8 and 30 weeks after immunization, the mice were given booster inoculations of 3 million cells. Three days after the last immunization, $10^{8}$ immune spleen cells were fused to $10^{7}$ NS-1 myeloma cells (14) with $30 \%$ polyethylene glycol 1000 (Koch-Light Laboratories, Ltd., Berks., England). Fused cells were plated in petri dishes in complete Iscove's medium containing $20 \% \mathrm{FCS}, 36 \mathrm{mM} \mathrm{NaHCO}_{3}$, and 50 $\mu \mathrm{g} / \mathrm{ml}$ garamycin. After a 48 -hr incubation at $37^{\circ}$, cells were plated in 96-well plates (Corning 25860) in complete Iscove's medium (Gibco Cat. No. 430-2200, Grand Island, New York) containing $1 \times 10^{-4} \mathrm{M}$ hypoxanthine, $1.6 \times 10^{-5} \mathrm{M}$ thymidine, and $4 \times 10^{-7} \mathrm{M}$ aminopterin (HAT) (15). The medium in each well was changed twice before testing for antibody production. Supernatant from wells containing hybrids was assayed for specific antibody by a mixed hemadsorption assay (13) against UM-SCC-1 cells. Positive supernatants were then tested against a panel of human cell lines including UM-SCC-1, a fibroblast line, a melanoma, and an ovarian carcinoma. Hybridomas giving unique patterns of reactivity were selected, subcloned, and the resulting monoclonal antibody-containing supernatants were tested extensively for reactivity to human malignant and normal cell lines of different histologic types. Established hybridoma cultures were maintained in Iscove's medium. Monoclonal antibody E7 is an IgM antibody that binds to nearly all human cells. 


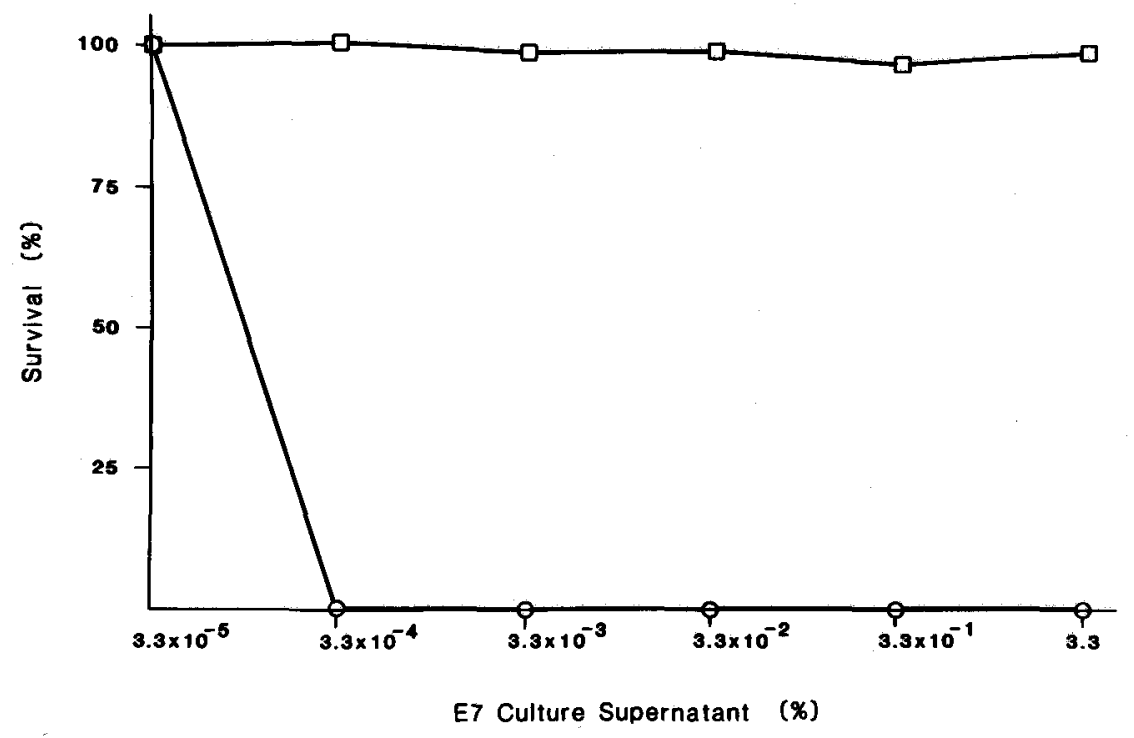

Fig. 1. Percentage survival in E7 monoclonal antibody and complement of CHO-K1 $\square$ and $\mathrm{J} 10$. In contrast to the $\mathrm{CHO}-\mathrm{K} 1$ parental cell, $\mathrm{J} 1$ was readily killed. The percentage survival is relative to a complement control.

Antigen Assay. Cells were plated in the presence of complement $(1.5 \%$ normal rabbit serum) in increasing concentrations of antiserum or hybridoma supernatant; 6 days later, the plates were fixed and stained, the number of colonies determined, and survival curves plotted. The difference between cells scored as killed or not killed is illustrated in Fig. 1.

Karyotypic and Isozyme Analysis of Hybrids. Human chromosome content of hybrids was determined cytogenetically by trypsin banding and Giemsa-11 staining $(8,16)$ and by analyzing isozymes specific for each human chromosome as previously described (17).

Glycolipid Conversion. The macroglycolipid (MGL) fraction of human red blood cell membranes was prepared by the method of Dejter-Juszynski et al. $(10,18)$. CHO-K1 cells were incubated with a solution of MGL $(1 \mathrm{mg} / \mathrm{ml})$ in PBS for $30 \mathrm{~min}$. Cells were then washed and tested with monoclonal antibody using the standard cytotoxicity assay. Control cells were incubated for $30 \mathrm{~min}$ in PBS.

\section{RESULTS}

Chromosomal Assignment. Survival curves showing the behavior of $\mathrm{J} 1$, a human-Chinese hamster hybrid containing chromosome 11 as its only human chromosome (8), and CHO-K1, the Chinese hamster parental cell line, when 
Table 1. Segregation Analysis of Antigen Recognized by E7 Monoclonal Antibody

\begin{tabular}{lll}
\hline Hybrid & \multicolumn{1}{c}{$\begin{array}{c}\text { Human chromosome } \\
\text { present }\end{array}$} & \multicolumn{1}{c}{$\begin{array}{c}\text { Killing action } \\
\text { displayed by E7 } \\
\text { monoclonal antibody }\end{array}$} \\
\hline $822-19 \mathrm{~B}$ & $1,2,3,5,6,10,11,14,15,19,20,21,22$ & \multicolumn{1}{|c}{ Killed } \\
$750-7$ & $4,9,11,16, \mathrm{X}$ & Killed \\
$68-11$ & $1,5,6,8,9,11,12,14,15,19,20,21,22, \mathrm{X}$ & Killed \\
$68-14$ & $4,5,6,7,8,9,11,12,14,15,18,19,20,21,22$ & Killed \\
$72-4 \mathrm{~B}$ & $3,8,10,11,12,17,21$ & Killed \\
$822-5 \mathrm{a}$ & $2,9,11,12,13,19,21,22$ & Killed \\
$68-12$ & $2,3,4,5,6,7,9,11,12,15,16,18,19,20,21,22$ & Killed \\
$822-59 \mathrm{~b}$ & $4,7,14$ & Not killed \\
$68-10 \mathrm{~A}$ & $4,8,12,14,15,18,19,21,22, \mathrm{X}$ & Not killed \\
$68-16$ & $5,6,8,21,22$ & Not killed \\
\hline
\end{tabular}

tested with the E7 monoclonal antibody are shown in Fig. 1. No complementmediated cytotoxicity is demonstrable for $\mathrm{CHO}-\mathrm{K} 1$ at concentrations of monoclonal antibody 1000 times greater than that which is completely lethal to $\mathrm{J} 1$. This provides evidence that this antigen activity is dependent on the presence of human chromosome 11 . To confirm this, a panel of independently isolated human-Chinese hamster hybrids which contain a combination of human chromosomes was tested with E7 monoclonal antibody. As shown in Table 1, there was $100 \%$ concordance of this activity with the presence of chromosome 11.

Regional Mapping. We have previously isolated and characterized a regional clone panel from $\mathrm{J} 1$ containing different deletions of chromosome 11 $(9,19)$. Members of this panel were tested with E7, and the results are shown in Table 2, which indicate the genetic component responsible for E7 activity resides on the short arm of 11 (11p13 $\rightarrow 11$ pter $)$.

Mutant Analysis. Because we have previously identified human antigens $a_{1}$ and $a_{3}$ with the same map location (9), we examined a mutant which was $\mathrm{a}_{1}{ }^{-} \mathrm{a}_{3}{ }^{+}$and contained a normal-appearing chromosome 11 (10). This mu-

Table 2. Characteristics of Hybrids and Human Cells Tested with E7 Monoclonal Antibody

\begin{tabular}{|c|c|c|c|}
\hline Cell & $\begin{array}{c}\text { Deletions in } \\
\text { chromosome } 11\end{array}$ & $\begin{array}{l}\text { Antigenic } \\
\text { phenotype }\end{array}$ & $\begin{array}{l}\text { Killing action displayed by } \\
\text { survival curve analysis to E7 } \\
\text { monoclonal antibody }\end{array}$ \\
\hline $\begin{array}{l}\text { J1 } \\
\text { J1-7 } \\
\text { J1-11 } \\
\text { J1-23 } \\
\text { J1-35 } \\
\text { HeLa } \\
\text { Altered HeLa }\end{array}$ & $\begin{array}{l}\text { None } \\
\text { p11 } \rightarrow \text { pter } \\
\text { q13 } \rightarrow \text { qter } \\
\text { p13 } \rightarrow \text { pter } \\
\text { None }\end{array}$ & $\begin{array}{l}a_{1}{ }^{+} a_{2}{ }^{+} a_{3}{ }^{+} \\
a_{1}{ }^{-} a_{2}{ }^{+} a_{3}{ }^{-} \\
a_{1}{ }^{+} a_{2}{ }^{-} a_{3}^{+} \\
a_{1}-a_{2}{ }^{+} a_{3}{ }^{-} \\
a_{1}-a_{2}{ }^{+} a_{3}{ }^{+} \\
a_{1}^{+} a_{2}{ }^{+} a_{3}^{+} \\
a_{1}{ }^{-} a_{2}{ }^{+} a_{3}^{+}\end{array}$ & $\begin{array}{l}\text { Killed } \\
\text { Not killed } \\
\text { Killed } \\
\text { Not killed } \\
\text { Not killed } \\
\text { Killed } \\
\text { Not killed }\end{array}$ \\
\hline
\end{tabular}


tant clone showed no cytotoxicity when tested with the monoclonal antibody (Table 2). This suggests that E7 may recognize the $a_{1}$ antigen but not $a_{3}$.

We have previously isolated and described a variant clone of HeLa which differs in morphology from the standard S3-HeLa (20). The altered HeLa has a round morphology and attaches poorly to plastic. Figure 2 compares the morphology of the altered HeLa with that of standard HeLa. We have previously shown that altered $\mathrm{HeLa}$ does not express the $\mathrm{a}_{1}$ antigen by its failure to adsorb $a_{1}$ activity from $a_{1}{ }^{+}$polyclonal antisera. It is also unable to elicit anti- $\mathrm{a}_{1}$ antibodies in rabbits in contrast to standard HeLa. Altered HeLa does express $\mathrm{a}_{2}$ and $\mathrm{a}_{3}$, two other chromosome 11 antigen-associated activities. The monoclonal E7 was, therefore, tested with these two HeLa cell lines, and it was found that standard HeLa was killed and altered HeLa was not (Table 2). Mutant analysis, therefore, shows that $\mathrm{a}_{1}$ and the antigen recognized by $E 7$ map on the same region of chromosome 11 and variants of both $\mathrm{J} 1$ and HeLa which have lost the $a_{1}$ antigen have lost the antigen recognized by $E 7$.

Glycolipid Conversion. We have previously shown that $\mathrm{a}_{1}$ antigenic activity is found in the macroglycolipid (MGL) fraction of the human erythrocyte membranes (10). Other workers have shown that it is possible to convert cholera toxin-resistant cells to cholera toxin sensitivity using the glycolipid $\mathrm{GM}_{1}$ ganglioside $(21,22)$. Lymphocytes have been made reactive to a teratoma-specific antiserum by treating them with organic extracts of teratoma cells (23). We therefore tested the ability of the MGL fraction to convert CHO-K1 cells to antigen positive. As was shown previously (Fig. 1), CHO-K1 cells are not killed by E7 at high concentrations but, as shown in Fig. 3, MGL treatment produced cells which were killed by the monoclonal antibody. This provides evidence that the MGL fraction which contained $a_{1}$ activity also has activity for E7. We therefore conclude that E7 recognized the same or a similar antigenic activity as that previously identified as $a_{1}$.

\section{DISCUSSION}

The availability of the E7 monoclonal antibody which recognizes the $a_{1}$ cell-surface antigenic determinant will allow further elucidation of the structure of this molecule. Monoclonal antibodies which are specific for single antigenic determinants will be particularly useful when studying complex structures like macroglycolipids. The E7 monoclonal antibody belongs to the IgM class and is extremely efficient in complement-mediated cytotoxicity tests, which makes it useful for the types of genetic analyses we use to study cell-surface molecules. It will also be useful for establishing the cellular and tissue distribution of this antigen. To date, the only human cell line identified which lacks this antigen is the altered HeLa clone, but more cell lines are 


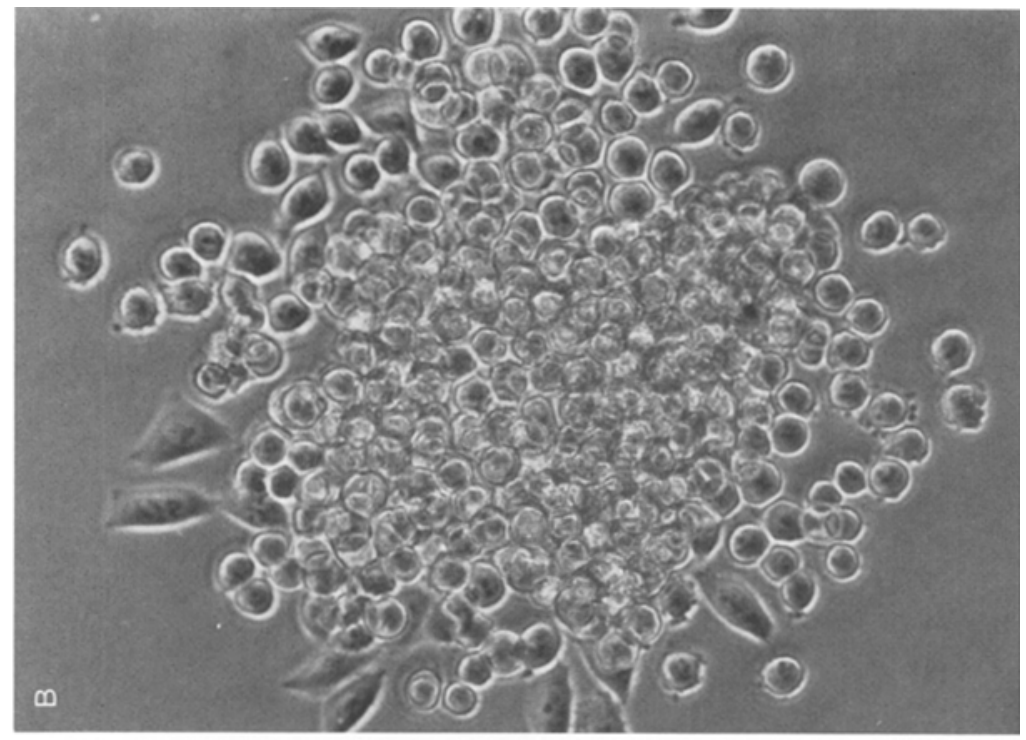

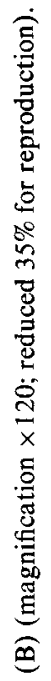

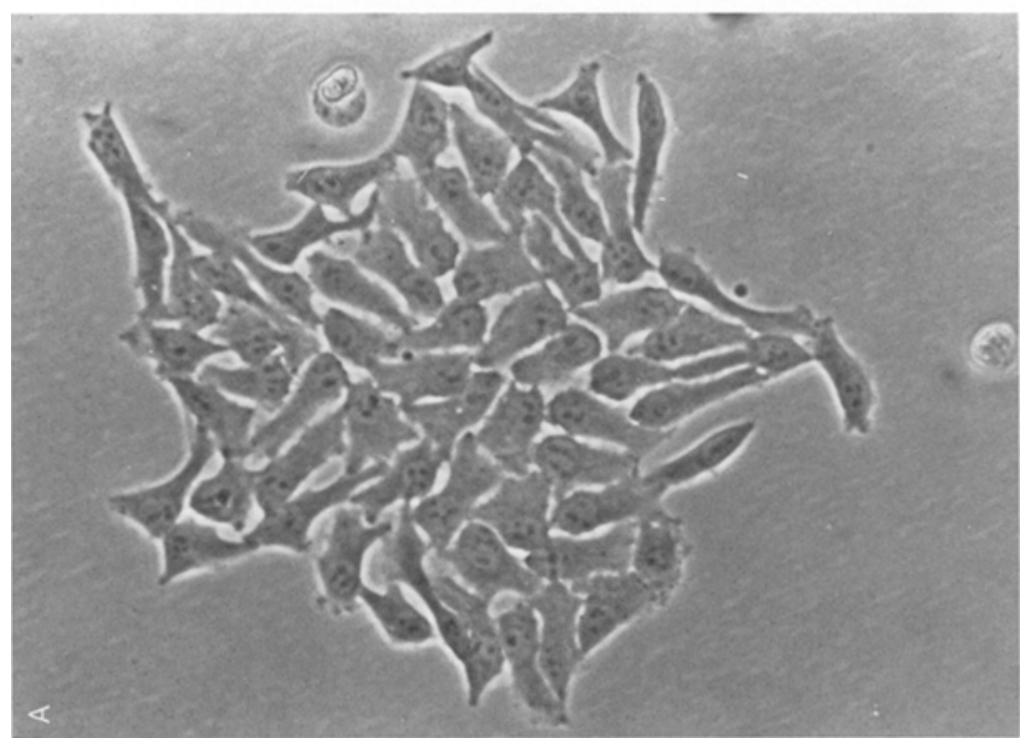

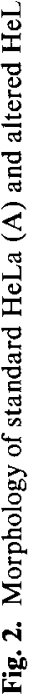




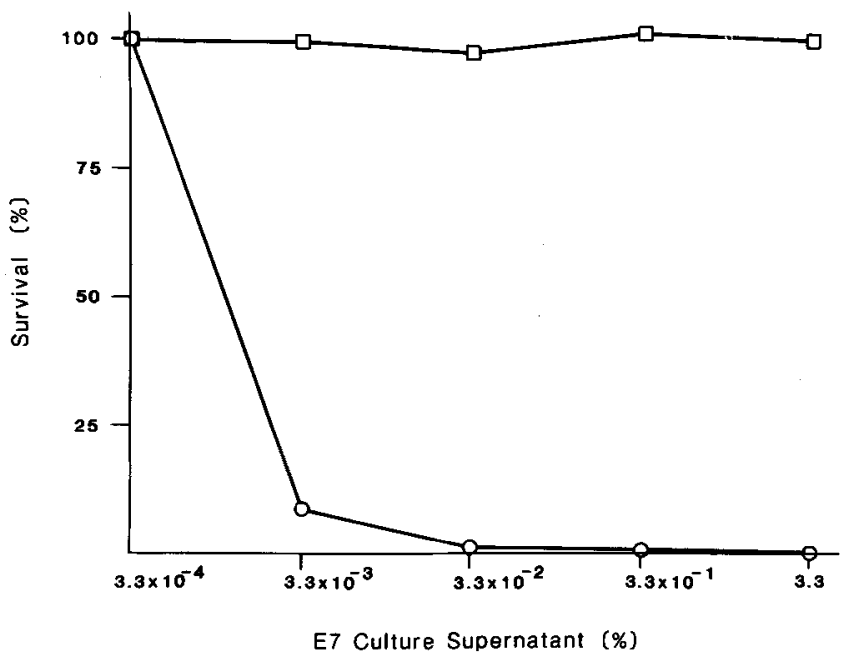

Fig. 3. Percentage survival in E7 monoclonal antibody and complement of control CHO-K1 and $\mathrm{CHO}-\mathrm{K} 1$ cells converted with the macroglycolipid fraction (MGL) of human red blood cell membranes 0 . Treatment of CHO-K1 with MGL converted this cell from one which was resistant to the action of E7 to one that was readily killed.

being tested and lines with significant quantitative differences have been identified.

A number of cell-surface molecules have been assigned to human chromosome 11. The relationship of these antigens to the antigens we have called $a_{1}, a_{2}$, and $a_{3}$ is not firmly established. Indeed we have genetic evidence that the activity we call $a_{2}$, which is encoded for by the long arm of 11 , consists of at least three separate activities. Barnstable et al. (5) have described monoclonal antibody which recognizes an antigen encoded for by the short arm of 11 which appears to be a glycolipid. This monoclonal antibody, W6-34, also appears to recognize the antigen we call $\mathrm{a}_{1}(24)$. This was determined using a similar experimental approach to that described for characterization of the E7 monoclonal antibody. We have also shown that the 105,000-dalton glycoprotein which is recognized by monoclonal antibody F10.44.2, assigned to chromosome 11 by Goodfellow et al. (6), maps on the same region of chromosome 11 as the $a_{3}$ antigen (24). Messer Peters et al. (7) have recently assigned an 85,000-dalton glycoprotein to chromosome 11 using a monoclonal antibody $4 \mathrm{~F} 2$, which appears different from those previously described.

The availability of these different monoclonal antibodies recognizing cell-surface antigens encoded for by human chromosome 11 should facilitate further manipulation and study of this human chromosome. 


\section{ACKNOWLEDGMENTS}

This is contribution (No. 425) from the Eleanor Roosevelt Institute for Cancer Research. This work was supported by USPHS grants CA 28564 and 18734 from the National Cancer Institute, Predoctoral Genetics Training Grant 1-T-32-GM-07544-05 awarded by the National Institutes of Health, and the Parker B. Francis Foundation. Thomas E. Carey is the recipient of a Research Career Development Award CA 00621 awarded by the National Cancer Institute.

\section{LITERATURE CITED}

1. Puck, T.T., Wuthier, P., Jones, C., and Kao, F.T. (1971). Proc. Natl. Acad. Sci. U.S.A. 68:3102-3106.

2. Jones, C., Wuthier, P., and Puck, T.T. (1975). Somat. Cell Genet. 1:235-246.

3. Buck, D.W., and Bodmer, W.F. (1975). Cytogenet. Cell Genet. 14:257-259.

4. Jones, C. and Puck, T.T. (1977). Somat. Cell Genet. 3:407-420.

5. Barnstable, C.J., Bodmer, W.F., Brown, F., Galfre, G., Milstein, C., Williams, A.F., and Ziegler, A. (1978). Cell 14:9-20.

6. Goodfellow, P.M., Banting, G., Wiles, M.V., Tunnacliffe, A., Parker, M., Solomon, E., Dalchau, R., and Fabre, J.W. (1982). Eur. J. Immunol. 12:659-663.

7. Messer Peters, P.G., Kamarck, M.E., Hemler, M.E., Strominger, J.L., and Ruddle, F.H. (1982). Somat. Cell Genet. 8:825-834.

8. Kao, F.T., Jones, C., and Puck, T.T. (1975). Proc. Natl. Acad. Sci. U.S.A. 73:193-197.

9. Jones, C., and Kao, F.T. (1978). Hum. Genet. 45:1-10.

10. Jones, C., Moore, E.E., and Lehman, D.W. (1979). Proc. Natl. Acad. Sci. U.S.A. 76:6491-6495.

11. Ham, R.G. (1965). Proc. Natl. Acad. Sci. U.S.A. 53:288-293.

12. Krause, C.J., Carey, T.E., Ott, R.W., Hurbis, C., McClatchey, K.D., and Regezi, J.A. (1981). Arch. Otolaryngol. 107:703-710.

13. Carey, T. E., Takahashi, T., Resnick, L.A., Oettgen, H.F., and Old, L.J. (1976). Proc. Natl. Acad. Sci. U.S.A. 73:3278-3282.

14. Kohler, G., and Milstein, C. (1976). Eur. J. Immunol. 6:511-519.

15. Kohler, G., and Milstein, C. (1975). Nature 256:495-497.

16. Bobrow, M., and Cross, J. (1974). Nature 251:77-79.

17. Jones, C., Kao, F.T., and Taylor, R.T. (1980). Cytogenet. Cell Genet. 28:181-194.

18. Dejter-Juszynski, M., Harpaz, N., Flowers, H.M., and Sharon, N. (1978). Eur. J. Biochem. 83:363-373.

19. Gusella, J., Varsanyi-Breiner, A., Kao, F.T., Jones, C., Puck, T.T., Keys, C., Orkin, S., and Housman, D. (1979). Proc. Natl. Acad. Sci. U.S.A. 76:5239-5243.

20. Moore, E.E. (1976). Dissertation (University of Colorado, Boulder, Colorado).

21. Cuatrecasas, P. (1973). Biochemistry 12:3558-3566.

22. Fishman, P.H., Moos, J., and Vaughn, M. (1976). J. Biol. Chem. 251:4490-4494.

23. Larraga, V., and Edidin, M. (1979). Proc. Natl. Acad. Sci. U.S.A. 76:2912-2916.

24. Tunnacliffe, A., Jones, C., and Goodfellow, P. (1983). Immunol. Today (in press). 